\title{
Growth improvement of Falcataria moluccana inoculated with MycoSilvi grown in post-mining silica sand soil medium amended with soil ameliorants
}

\author{
SRI WILARSO BUDI", CAHYO WIBOWO, ANDI SUKENDRO, HABIB SATRIO BEKTI \\ Department of Silviculture, Faculty of Forest, Institut Pertanian Bogor. Jl. Lingkar Akademik Kampus IPB, Dramaga, Bogor 16680, West Java, \\ Indonesia. Tel.: +62-251-86268806, Fax.: +62 251 8626886, `email: wilarso62@yahoo.com.
}

Manuscript received: 5 November 2019. Revision accepted: 31 December 2019.

\begin{abstract}
Budi SW, Wibowo C, Sukendro A, Bekti HS. 2020. Growth improvement of Falcataria moluccana inoculated with MycoSilvi grown in post-mining silica sand soil medium amended with soil ameliorants. Biodiversitas 21: 422-427. High aluminum content in soil of post-mining silica sand area inhibits plant growth. MycoSilvi is an inoculum of Arbuscular Mycorrhizal Fungi (FMA) enriched with Mycorrhizal Helper Bacteria (MHBs) which plays an important role for improving plant growth in unfertile soil medium. The aims of this research were to analyze the growth response of Falcataria moluccana (Miq.) Barneby \& JW Grimes) seedlings treated with MycoSilvi and soil ameliorants (compost and lime) in post-mining silica sand soil medium. The randomized complete design with factorial scheme was used in this study. The results showed that the interactions of MycoSilvi and Soil ameliorant significantly increased height, diameter, biomass and mycorrhizal colonization of $F$. moluccana. Combination of MycoSilvi variant 3 and lime increased height, diameter, and biomass of $F$. moluccana by $965 \%, 147 \%$, and $1427 \%$ respectively, as compared to those of control plants. The mycorrhizal roots colonization in those treatments was $98 \%$. The addition of compost and lime increased $\mathrm{pH}$ and decreased Aluminum and Fe of the soil medium. F. moluccana seedlings have high mycorrhizal dependency on post-mining silica sand soil media. These results indicate prospective uses of MycoSilvi and soil ameliorants for improving plant growth in unfertile soil medium, including soil in post-mining area.
\end{abstract}

Keywords: Aluminum, Falcataria moluccana, MycoSilvi, post mining, soil ameliorant

\section{INTRODUCTION}

Mining activities are mostly carried out by open mining method, which causes scraping of the upper soil surface. This open mining system will cause deterioration of soil properties, including physical properties, chemical properties and biological properties of the soil (Arshi 2015). Changes in soil properties can result in land degradation as indicated by structural indicators such as low total plant cover, low perennial and annual plant species richness, low aboveground Phyto mass, low beta diversity, decreased life form spectrum, reduced number of keystone species, low soil microbial biomass, low soil microbial diversity, as well as functional indicators such as low biomass productivity, low soil organic matter and poor soil water retention (Asmelash et al. 2016). Degraded lands are also characterized by low levels of Arbuscular Mycorrhizal Fungi (AMF) abundance and diversity (Cardozo-Junior et al. 2012). Plants can not grow normally in degraded land as reported by Widyati (2006) due to low $\mathrm{pH}$ and solubility of heavy metals.

The solubility of heavy metal, especially $\mathrm{Al}$ and $\mathrm{Fe}$ in the soil, greatly correlated with soil $\mathrm{pH}$ (Delhaize and Ryan 1995). When soil $\mathrm{pH}$ was bellow 5.5, $\mathrm{Al}^{3+}$ become dominant and constituted the most toxic form for plant growth and development (Kochian et al. 2004). $\mathrm{Al}^{3+}$ element is a limiting factor in plant growth and development, and caused phenomena such as stunted root growth and root extension to take soil nutrients (Silva 2012). Toxic elements cause deviations of physiological and biochemical processes during plant growth (Barchia 2009). The presence of high $\mathrm{Al}$ and $\mathrm{Fe}$ content in postmining land have been reported by Jayani et al. (2018) and inhibited the early growth of three species of forest seedlings.

Several soil ameliorants have been used by many researchers for improving plant growth and development in acidic soil medium (Ohsowski et al. 2017; Mrabet et al. 2014; Moreira et al. 2010). The use of lime for increasing soil $\mathrm{pH}$ has been reported by several researchers (Mrabet et al. 2014, Jayani et al. 2018; Guo and Huang 2010). The use of compost and biochar for improving plant growth and development in post-mine sandpits were well documented (Ohsowski et al. 2017). Some researchers used Arbuscular Mycorrhizal Fungi for improving plant growth in acidic soil medium (Husna et al. 2015; Husna et al. 2019) and in heavy metal contaminated soil (Setyaningsih et al. 2018). In the rhizosphere, AMF interacts positively with biochar and give synergetic effect to plant growth (Budi and Christina 2013; Budi and Setyaningsih 2013). Positive interaction of compost, lime, and AMF which was formulated as MycoSilvi inoculum, containing Glomus mosseae and Mycorrhizal Helper Bacteria (MHBs) have been reported by Jayani et al. (2018) and can improve early growth of forest trees seedling grown in post-mine soil medium.

In this research, we develop a new variant of MycoSilvi which consists of three variants, namely MycoSilvi variant 
1 containing Glomus mossea, MycoSilvi variant 2 containing G. mosseae and Acaulopora sp, and MycoSilvi variant 3 containing G. mosseae, Acaulopora sp., and Gigaspora margarita. We hypothesize that MycoSilvi containing more than one AMF species will be more effective than one AMF species. The aim of this study was to analyze growth response of Falcataria moluccana seedlings inoculated with different variants of MycoSilvi, and the seedlings were grown in post silica sand-mine soil medium amended with lime and compost.

\section{MATERIALS AND METHODS}

\section{Germination of Falcataria moluccana seeds}

The experiment was carried out in greenhouse at the Department of Silviculture, Faculty of Forestry, IPB University, Bogor, Indonesia. F. moluccana seeds, obtained from the Center of Research and Development for Forest Seed, Bogor Indonesia, were soaked in hot water $\left(80^{\circ} \mathrm{C}\right)$ for one hour and were further soaked in cold water for 24 hours for breaking their dormancy. The seeds were then sown in a plastic box, containing sterile zeolite and watered daily as needed.

\section{Preparation of soil growth medium}

The soil medium was collected from silica post-mining area of PT Holcim Indonesia, Tbk, Sukabumi, West - Java. The soil medium was then air-dried, sieved with soil sieve of $2 \mathrm{~mm}$ and autoclaved at $1.5 \mathrm{psi}, 120^{\circ} \mathrm{C}$ for one hour. The physicochemical characteristics of soil medium have been analyzed at Soil Laboratory, Faculty of Agriculture, IPB University comprising the following variables : $\mathrm{pH}\left(\mathrm{H}_{2} \mathrm{O}\right)$ (3.56); C-organic (1.65\%); N-total (0.29\%); P-total (46.18 $\mathrm{mg} / 100 \mathrm{~g})$; P-available $(4.25 \mathrm{mg} / 100 \mathrm{~g})$; Ca $(0.26 \mathrm{cmol} / \mathrm{kg})$; $\mathrm{Mg}(0.29 \mathrm{cmol} / \mathrm{kg}) ; \mathrm{K}(0.10 \mathrm{cmol} / \mathrm{kg}) ; \mathrm{Na}(0.04 \mathrm{cmol} / \mathrm{kg}) ;$ CEC (11.02 cmol/kg); Al (5.75 cmol/kg); Fe (182.98 ppm). The soil showed the following soil texture: Sand $37.95 \%$; Silt $27.01 \%$ and Clay 35.04\%. Lime was obtained from farmer market as dolomite. Organic compost was obtained from CV. Cahaya Gemilang, Bogor Indonesia and have the following chemical characteristics: $\mathrm{pH}\left(\mathrm{H}_{2} \mathrm{O}\right)$ (7.61; Corganic (47.14\%); N-total (1.10\%); ratio $\mathrm{C} / \mathrm{N}(42.68) ; \mathrm{P}_{2} \mathrm{O}_{5}$ $(1.67 \%) ; \mathrm{K}_{2} \mathrm{O}(2.44 \%)$ and moisture content (15.66\%). Sterilized soil medium was then mixed or not with organic compost and lime, and filled to polybag 15 x $20 \mathrm{~cm}$.

\section{Preparation of MycoSilvi inoculum and inoculation of plants}

MycoSilvi inoculum was produced in plastic pot of 1000 $\mathrm{ml}$ containing zeolite sterile medium by using Pueraria javanica as host plants for two months. At harvest, the number of AMF spores per gram medium was counted and stored in refrigerator until used.

$F$. moluccana seedlings that have aged two weeks in plastic box containing zeolite sterile medium were transferred in to polybag filled with sterilized growing medium. MycoSilvi were inoculated to the healthy and uniform $F$. moluccana seedlings. Each plant received $5 \mathrm{~g}$ of MycoSilvi inoculum (containing 50 spores of Arbuscula
Mycorrhizal Fungi). AMF inoculation was conducted near the root system of the plants and the height and stem diameter of the seedlings was determined at the AMF inoculation as an early baseline data.

\section{Parameters evaluation}

The evaluation of variables was carried out at 12 weeks after inoculation of $F$. moluccana seedlings, comprising the following variables: plant height, stem diameter, dry biomass, and mycorrhizal root colonization. Plant heights were determined by measuring tape, stem diameter by using digital caliper, and plant biomass was determined after drying in oven at $70^{\circ} \mathrm{C}$ for 72 hours. The estimation of percentage of mycorrhizal root colonization was carried out after bleaching and staining, according to the method described by Phylip and Hayman (1970). The quantification of mycorrhizal roots colonization was performed by a method of Brundrett et al. (1996). The growth response (GR) of $F$. moluccana was calculated according to the formula developed by Hetrick et al. (1996), while the mycorrhizal dependence (MD) was calculated according to the method of Plenchette et al. (1983).

\section{Experimental design and data analysis}

The experimental design was randomized complete design, in $4 \times 2 \times 2$ factorial scheme, with 4 MycoSilvi treatments: control (not inoculated), inoculated with MycoSilvi variant1, inoculated with MycoSilvi variant 2, and inoculated with MycoSilvi variant 3); two organic compost doses ( $0 \mathrm{~g}$ and $32.5 \mathrm{~g}$ )/650 g growth medium; and two lime doses $(0 \mathrm{~g}$ and $7.2 \mathrm{~g}) / 650 \mathrm{~g}$ growth medium. Each treatment was replicated five times. Analysis of variance was carried out, followed with Duncan test to compare all treatments.

\section{RESULTS AND DISCUSSION}

\section{Effect of MycoSilvi and soil ameliorants on plant growth}

It is well known that inhibition of plant growth is mainly due to inadequate levels of any nutrients (Lambers et al. 1998 ) as well as the availability of toxic elements in soil media such as Al and Fe (Silva 2012). Bioavailability and toxicity of $\mathrm{Al}$ occurs mainly on acid soil with $\mathrm{pH}$ below 5.5, and consequently decreased crop production (Alori and Fawole 2012; Silva 2012). According to Yamamoto (2019), the plant cell deaths were triggered by Aluminum due to enhancement of Fe-mediated lipid peroxidation, leading to a loss of plasma membrane integrity, dysfunction of mitochondria followed by Reactive Oxygen Species (ROS) production and vacuolar collapse due to upregulation of a vacuolar processing enzyme. In this research, the medium growth being used had low $\mathrm{pH}\left(\mathrm{H}_{2} \mathrm{O}\right)$ (3.56); low C-organic content (1.65\%); low N-total (0.29\%); low P-available (4.25 mg/100g); high $\mathrm{Al}(5.75 \mathrm{cmol} / \mathrm{kg}) ;$ and high $\mathrm{Fe}(182.98 \mathrm{ppm})$. Consequently, control plants without soil amendment and not inoculated with MycoSilvi showed stunted growth as compared to other treatments (Table 1). On the contrary, 12 weeks old $F$. moluccana seedlings inoculated with 
MycoSilvi significantly showed increased height, stem diameter and biomass for all MycoSilvi variants (Table 1). The plant height, stem diameter, and biomass increased differently in line with MycoSilvi variants being used, regardless of soil amendment application (Table 1). The plant heights were increased by $24 \%, 293 \%$, and $575 \%$ when inoculated with MycoSilvi variant 1,2 and 3 respectively (Table1), while the plant stem diameter with the same treatment was increased by $79 \%, 91 \%$, and $102 \%$ respectively as compared to control. The plant biomass also showed similar results when plants were inoculated with MycoSilvi variants 1, 2 and 3, which were increased by $317 \%$, $883 \%$, and $926 \%$ respectively as compared to control plant.

Plant growth improvement by MycoSilvi variant 3 showed better results than those by MycoSilvi variant 2 dan variant 1 , due to different AMF species contained in the MycoSilvi. MycoSilvi variant 1 contained one AMF species Glomus mosseae, while MycoSilvi variant 2 and 3, contained two and three AMF species, namely G. mosseae and Acaulospora sp and G. mosseae, Acaulospora sp and Gigaspora maragarita respectively. These results were in agreement with Chen et al. (2017), who found that Cucumber seedling growth was better when inoculated with five AMF species than four or one AMF species. AMF has an extrametrical hyphae network in the plant rhizosphere and plays important roles not only in promoting plant growth in degraded soil (Berruti et al. 2016) but also improving soil aggregation (Borie et al. 2008 ) and soil chemical properties (Pal and Pandey 2017). AMF also plays an important role in the nutrient uptake from soil medium, especially Nitrogen (Bucking and Kafle 2015) and Phosphor (Goussous and Mohammad 2009). In addition, AMF also produced phosphatase enzyme and have been reported by several researchers (Bini et al. 2017; Sultana and Siddique 2015; Wang et al. 2011). This enzyme plays an important role in releasing $\mathrm{Al} / \mathrm{Fe}-\mathrm{P}$ bound in acid soil and absorbed by mycorrhizal hyphae or root plant. In this study, plants inoculated with AMF showed better growth than control plant, indicating that MycoSilvi has been functioned, as shown also by mycorrhizal roots colonization (Table 1).

The roles of organic compost for improving plant growth in acid soil have been reported by several researchers (Escobar and Hue 2008; Bougnom et al. 2010; Medina and Azcon 2010). This organic material have a direct effect on reduced Al toxicity, increased soil organic matter content, increased soil $\mathrm{pH}$ and soil biota, increased aggregate stability, soil enzymatic activities, water-soluble $\mathrm{C}$ and water-soluble carbohydrates, as well as nutrient availability, especially $\mathrm{P}$. In this research, addition of compost to soil medium increased plant height, stem diameter and biomass by $105 \%, 50 \%$, and $113 \%$ respectively as compared to control plant (Table 1). Interestingly, addition of compost to soil medium can improve AMF growth and development as indicated by increasing percentage of mycorrhizal roots colonization (Table 1), and consequently increased plant height, stem diameter, and biomass. Interaction between MycoSilvi variant 1 and compost increased plant height, stem diameter and biomass by $961 \%, 131 \%$, and $1736 \%$ respectively as compared to control plant. On the other hand, the interaction between MycoSilvi variant 1 and compost increased plant height, stem diameter and biomass by $521 \%, 121 \%$, and $1347 \%$ respectively, as compared to control plant. The similar results when plant inoculated by MycoSilvi variant 3 combined with compost, can increased plant height, steam diameter, and biomass by $510 \%, 110 \%$ and $803 \%$ respectively as compared to control plant. Our results are contrary to those of Mrabet et al. (2014), who found that mycorrhizal plants in soil media not amended with bio-compost showed higher percentages of root colonization than those of inoculated plants planted in amended soils, and therefore bio-compost had a negative effect on AMF development. This was due to different chemical characteristics of soil medium and compost used in this study especially $\mathrm{pH}$ and $\mathrm{C} / \mathrm{N}$ ratio.

Tabel 1. The effect of MycoSilvi and soil ameliorants on the growth of Falcataria moluccana, 12 weeks after planting

\begin{tabular}{|c|c|c|c|c|c|c|}
\hline \multirow{2}{*}{ MycoSilvi } & \multicolumn{2}{|c|}{ Soil ameliorant } & \multirow{2}{*}{ Height $(\mathbf{c m})^{*}$} & \multirow{2}{*}{ Diameter $(\mathbf{m m}) *$} & \multirow{2}{*}{ Biomass (g)* } & \multirow{2}{*}{$\begin{array}{c}\text { \% Mycorrhizal roots } \\
\text { colonization }\end{array}$} \\
\hline & Compost & Lime & & & & \\
\hline \multirow{4}{*}{ Without MycoSilvi } & - & - & $1.83 \mathrm{f}$ & $1.06 \mathrm{i}$ & $0.14 \mathrm{~g}$ & 0 \\
\hline & + & - & $3.75 \mathrm{f}$ & $1.59 \mathrm{~h}$ & $0.30 \mathrm{fg}$ & 0 \\
\hline & - & + & $4.07 \mathrm{f}$ & $1.73 \mathrm{gh}$ & $0.76 \mathrm{ef}$ & 0 \\
\hline & + & + & $1.88 \mathrm{f}$ & $1.04 \mathrm{i}$ & $0.21 \mathrm{fg}$ & 0 \\
\hline \multirow[t]{4}{*}{ MycoSilvi var 1} & - & - & $2.70 \mathrm{f}$ & $1.90 \mathrm{fg}$ & $0.58 \mathrm{fg}$ & 66 \\
\hline & + & - & $19.37 \mathrm{a}$ & $1.59 \mathrm{~h}$ & $2.57 \mathrm{a}$ & 94 \\
\hline & - & + & $17.31 \mathrm{ab}$ & $2.76 \mathrm{a}$ & $2.22 \mathrm{ab}$ & 100 \\
\hline & + & + & $10.88 \mathrm{~d}$ & $2.11 \mathrm{def}$ & $1.39 \mathrm{~d}$ & 98 \\
\hline \multirow[t]{4}{*}{ MycoSilvi var 2} & - & - & $7.18 \mathrm{e}$ & $2.03 \mathrm{ef}$ & $1.38 \mathrm{~d}$ & 68 \\
\hline & + & - & $12.26 \mathrm{dc}$ & $2.35 \mathrm{~cd}$ & $2.03 \mathrm{abc}$ & 100 \\
\hline & - & + & $17.90 \mathrm{a}$ & $2.69 \mathrm{ab}$ & $1.69 \mathrm{bcd}$ & 100 \\
\hline & + & + & $12.88 \mathrm{dc}$ & $2.15 \mathrm{def}$ & $1.79 \mathrm{bcd}$ & 98 \\
\hline \multirow{4}{*}{ MycoSilvi var 3} & - & - & $12.33 \mathrm{dc}$ & $2.15 \mathrm{def}$ & $1.44 \mathrm{~d}$ & 62 \\
\hline & + & - & $11.15 \mathrm{~d}$ & $2.24 \mathrm{cde}$ & $1.26 \mathrm{de}$ & 78 \\
\hline & - & + & $19.45 \mathrm{a}$ & $2.63 \mathrm{ab}$ & $2.14 \mathrm{ab}$ & 98 \\
\hline & + & + & $14.67 b c$ & $2.02 \mathrm{ef}$ & $1.49 \mathrm{~cd}$ & 78 \\
\hline
\end{tabular}

Note: *Values followed by the same letter (s) in the same columns are not significantly different at $\mathrm{p}<0.05$, Duncan's Multiple Range Test (DMRT) 
Table 2. Chemical characteristics of soil medium after treatment at the end of experiment

\begin{tabular}{|c|c|c|c|c|c|}
\hline \multirow[b]{2}{*}{ MycoSilvi } & \multicolumn{2}{|c|}{ Soil ameliorant } & \multirow[b]{2}{*}{$\mathbf{p H}\left(\mathrm{H}_{2} \mathrm{O}\right)$} & \multirow[b]{2}{*}{$\mathrm{Al}(\mathrm{mg} / \mathrm{kg})$} & \multirow{2}{*}{$\mathrm{Fe}(\mathrm{mg} / \mathrm{kg})$} \\
\hline & Compost & Lime & & & \\
\hline \multirow[t]{4}{*}{ Without MycoSilvi } & - & - & 4.65 & 224.54 & 138.23 \\
\hline & + & - & 4.32 & 181.97 & 163.91 \\
\hline & - & + & 6.17 & 36.77 & 20.96 \\
\hline & + & + & 5.93 & 48.22 & 41.00 \\
\hline \multirow[t]{4}{*}{ MycoSilvi var 1} & - & - & 4.18 & 169.39 & 94.05 \\
\hline & + & - & 4.20 & 154.44 & 172.35 \\
\hline & - & + & 6.84 & 19.10 & 15.42 \\
\hline & + & + & 6.60 & 33.72 & 31.42 \\
\hline \multirow[t]{4}{*}{ MycoSilvi var 2} & - & - & 3.90 & 173.37 & 89.86 \\
\hline & + & - & 4.31 & 135.17 & 117.79 \\
\hline & - & + & 7.06 & 18.66 & 13.25 \\
\hline & + & + & 6.95 & 28.30 & 22.22 \\
\hline \multirow[t]{4}{*}{ MycoSilvi var 3} & - & - & 3.90 & 180.37 & 105.76 \\
\hline & + & - & 4.27 & 146.42 & 128.43 \\
\hline & - & + & 7.28 & 17.57 & 13.05 \\
\hline & + & + & 7.18 & 21.47 & 16.77 \\
\hline
\end{tabular}

The positive effects of liming in acid soils for improving plant growth are well documented (Bambara and Ndakidemi 2009; Guo and Huang 2010; Moreira et al. 2010). In this study, soils amended by lime increased plant height, stem diameter and biomass by $123 \%, 62 \%$, and $444 \%$ respectively as compared to those of control plants (Table 1). As reported by Furtini-Neto et al. (2004), liming can increase soil $\mathrm{pH}$ and reduces the fixation of $\mathrm{P}$ by $\mathrm{Al}$ and $\mathrm{Fe}$, stimulates roots growth and finally increase nutrient uptake by plant roots. In our study, liming can increase soil $\mathrm{pH}$, decrease $\mathrm{Al}$ and $\mathrm{Fe}$ in soil media (Table 2).

The interesting finding from this research is that the lime increased AMF development, as indicated by increasing mycorrhizal roots colonization in all variants of MycoSilvi being applied (Table 1). Consequently, the growth of plants also increased significantly. Interaction between MycoSilvi variant 1 and lime increased significantly plant height, stem diameter and biomass by $847 \%, 159 \%$, and $1486 \%$ respectively as compared to control plants, while MycoSilvi variant 2, when combined with lime, increased significantly plant height, stem diameter, and biomass by $880 \%, 152 \%$, and $1106 \%$ respectively. The same combination with MycoSilvi variants 3 increased significantly plant height, stem diameter and biomass by $965 \%, 147 \%$, and $1427 \%$ respectively. In this study, as shown in Table 2, lime facilitated the increase of soil $\mathrm{pH}$ and decrease of $\mathrm{Al}$ content in soil growth medium, and such conditions become favorable for root growth which is preferable site for AMF development. Our finding confirms the results reported by Bambara and Ndakdemi (2009), Moreira et al. (2010) and Guo and Huang (2010).

The interaction between MycoSilvi, compost, and lime have been reported by Jayani et al. (2018), who found that plants inoculated with AMF and combined with lime and compost in growth medium, significantly increased height and diameter growth by 148.3 and $155.9 \%$ respectively as compared to plants inoculated with MycoSilvi combined with lime alone in soil growth medium. On the contrary, in our results, plants inoculated with MycoSilvi and combined with compost and lime, showed reduced plant height and diameter as compared to plants inoculated with MycoSilvi combined with lime alone in soil growth medium. The extent of decreasing plant height and diameter varied, depending on MycoSilvi being used. When soil growth media were amended with lime and compost, and the plants were inoculated with MycoSilvi variant 1, 2 and 3, the plant heights were reduced by $59.1 \%, 38.9 \%$, and $32.6 \%$ respectively, and diameter growth was reduced by $30.8 \%$, $25.1 \%$ and $30.2 \%$ respectively, as compared to plants inoculated with MycoSilvi combined with lime alone in soil growth medium. These different results are probably due to different $\mathrm{C} / \mathrm{N}$ ratio of compost being used. In our research compost has high $\mathrm{C} / \mathrm{N}$ ratio, namely 42.68 , while Jayani et al. (2018) used compost with $\mathrm{C} / \mathrm{N}$ ratio 25.76 . According to Kuzyakov and Xu ( 2013), organic compost with high $\mathrm{C} / \mathrm{N}$ ratio may inhibit plant growth due to nutrient competition between decomposer microorganisms and plant roots.

\section{Relative mycorrhizal dependency and growth response of Falcataria moluccana}

The potential role of AMF in restoration of degraded land has been reported by Asmelash et al. (2016), and the contribution of AMF to plant growth depends on soil fertility. The degree in which a plant is dependent on the mycorrhizal condition to produce its maximum growth or yield, at a given level of soil fertility is called mycorrhizal dependency (Gerdemann 1975). In our research, the degree of mycorrhizal dependency of $F$. moluccana varied depended on the combined treatments (Figure 1). $F$. moluccana inoculated by MycoSilvi variant 1, 2 and 3, without soil amendment had relative mycorrhizal dependency $76 \%, 90 \%$, and $90 \%$ respectively. These results were in agreement with Jha et al. (2012), who found that maximum mycorrhizal dependency of Bamboo species was achieved by plants inoculated with Acaulospora scrobiculata, 


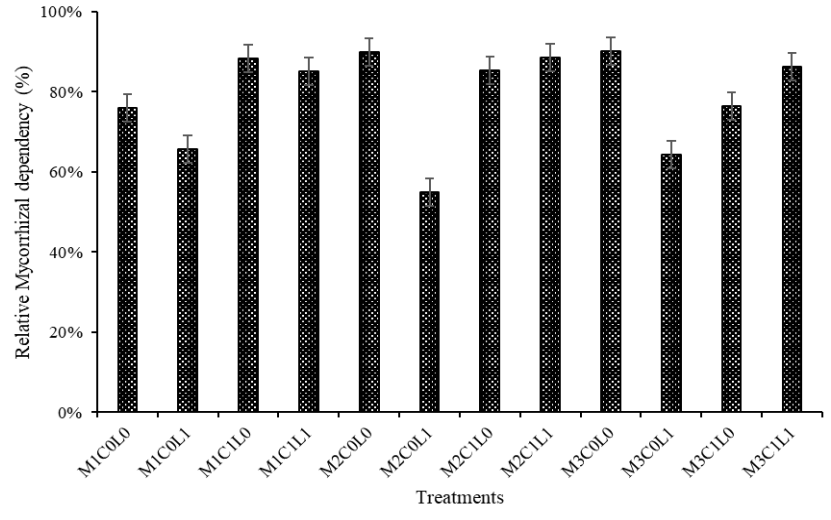

Figure 1. Interaction of MycoSilvi (M1: MycoSilvi variant 1, M2: MycoSilvi variant 2, M3: MycoSilvi variant 3), Compost (C0: $0 \mathrm{~g}$ compost, $\mathrm{C} 1: 32.5 \mathrm{~g}$ compost) and Lime (L0: $0 \mathrm{~g}$ lime, L1: $7.2 \mathrm{~g}$ lime) on Relative Mycorrhizal Dependency of $F$ Falcataria moluccana

followed by Glomus cerebiforme and G. intraradis. In our results, the maximum relative mycorrhizal dependency of F. moluccana was recorded for MycoSilvi variant 3 which contained Glomus mosseae, Acaulospora sp. and Gigaspora margarita, followed by MycoSilvi variant 2 which contained G. mosseae and Acaulospora sp. (Figure 1).

The degree of relative mycorrhizal dependency was also affected by soil condition as reported by previous researchers (Renuka et al. 2012) who found that the relative mycorrhizal dependency of Acacia melanoxylon correlated with the degree of disturbance of the soil which is characterized by unfertile soil. As shown in Figure 1, the relative mycorrhizal dependency of $F$. moluccana inoculated with MycoSilvi variants 1, 2 and 3 and treated with lime were decreased by $66 \%, 55 \%$, and $64 \%$ respectively, indicating that liming effectively increased soil $\mathrm{pH}$ and released $\mathrm{P}$ to the soil growth medium, and finally plant roots can absorb normally and dependency to mycorrhizae decreased. On the contrary, the addition of compost increased relative mycorrhizal dependency of $F$. Moluccana by $88 \%, 85 \%$ and $76 \%$ for MycoSilvi variant 1 , 2 and 3 respectively, probably due to the $\mathrm{C} / \mathrm{N}$ ratio of compost used in this study which was quite high.

The responsiveness of plant to mycorrhizal inoculation was called as growth response (Plenchette et al. 1983). Figure 2 presented the growth response of $F$. moluccana as affected by soil amendment. $F$. moluccana was very responsive to MycoSilvi variant 3, followed by MycoSilvi variant 2 and Variant 1.

The difference of mycorrhizal dependency and responsiveness was due to differences in plant species (Tawaraya 2003) and differences in the development of external hyphae and nutrient uptake from the soil (Smith et al. 2000). The addition of lime and compost to soil medium increased soil $\mathrm{pH}$ and decreased Aluminium and $\mathrm{Fe}$ in the soil (Table 2), and consequently plant roots grow better for absorbing nutrients from the soil and finally decreased the growth responsiveness of F. moluccana (Figure 2).

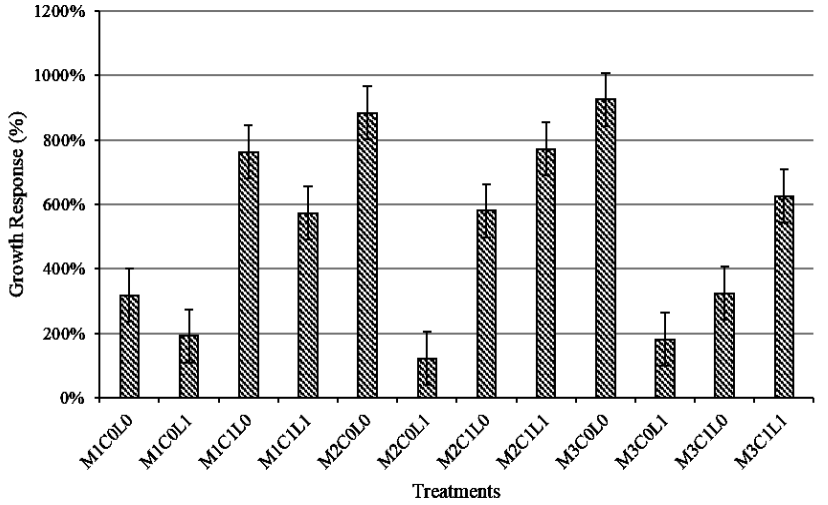

Figure 2. Growth response of Falcataria moluccana as affected by MycoSilvi (M1: MycoSilvi variant 1, M2: MycoSilvi variant 2, M3: MycoSilvi variant 3), Compost (C0: 0 g compost, C1: 32.5 $\mathrm{g}$ compost) and Lime (L0: $0 \mathrm{~g}$ lime, L1: $7.2 \mathrm{~g}$ lime)

The important findings of this research were that postmining soil which was characterized by very low soil fertility could be improved for $F$. moluccana plant growth by application of MycoSilvi, lime and compost alone or in combination. To maximize the positive effect of MycoSilvi on plant growth, lime or compost can be added to soil growth medium. Based on our results, MycoSilvi variant containing more than one AMF species was better than those which contain only one AMF species. F. moluccana has a high growth response and mycorrhizal dependency on degraded soil. These findings imply the prospective use of MycoSilvi and soil ameliorant for improving plant growth in unfertile soil medium, including soil in post-mining area, and support the success of rehabilitation of degraded land area.

\section{ACKNOWLEDGEMENTS}

The authors wish to express their gratitude to Directorate for Research and Community Services, Ministry of Research, Technology, and Higher Education, the Republic of Indonesia, for providing the research grant in accordance with the Letter of Agreement of Implementation Research Grant No. 1786/IT3.11/PN/2018 dated 21 February 2018 and No. 4191/IT.3.1.1/PN/2019 dated 4 April 2019. The authors also wish to thank PT Holcim Indonesia Tbk., Sukabumi, West Java, for providing soil media in this research.

\section{REFERENCES}

Alori E, Fawole O. 2012. Phytoremediation of soils contaminated with aluminum and manganese by two arbuscular mycorrhizal fungi $\mathrm{J}$ Agric Sci 4: 8. DOI:10.5539/jas.v4n8p246.

Arshi A. 2015. Reclamation of coal mine overburden dump through environmental friendly method. Saudi J Biol Sci 24: 371-378. 
Asmelash F, Bekele T, Birhane E. 2016. The potential role of arbuscular mycorrhizal fungi in the restoration of degraded lands. Front Microbiol 7: 1095. DOI:10.3389/fmicb.2016.01095.

Bambara S, Ndakidemi PA. 2009. Effect of rhizobium inoculation, lime and molybdenum on photosynthesis and chlorophyll content of Phaseolus vulgaris L. Afr J Microbiol Res 3: 791-798.

Barchia MF. 2009. Acid Mineral Soil Agroecosystem. Gadjah Mada University Press, Yogyakarta. [Indonesian]

Berruti A, Lumini E, Balestrini R, Bianciotto V. 2016. Arbuscular mycorrhizal fungi as natural biofertilizers: Let's benefit from pas successes. Front Microbiol 6: 1559. DOI:10.3389/fmicb.2015.01559.

Bini D, Alcara dos Santos C, da Silva MCP, Bonfirm JA, Cardoso EJBN 2017. Intercropping Acacia mangium stimulates AMF colonization and soil phosphatase activity in Eucalyptus grandis. Scientia Agricola 2: 102-110.

Borie F, Rubio R, Morales A. 2008. Arbuscular mycorrhizal fungi and soil aggregation. J Soil Plant Nutr 8: 9-18.

Bougnom BP, Knapp BA, lhottova DE, Koubova A, Etoa FX, Insam H. 2010. Designer compost with biomass ashes for ameliorating acid tropical soils: Effects on the soil microbiota. Appl Soil Ecol 45: 319 324

Brundrett MC, Ashwath N, Jasper DA. 1996. Mycorrhizas in the Kakadu region of tropical Australia. II Propagules of mycorrhizal fungi disturbed habitats. Plant Soil 184: 173-184

Bucking H, Kafle A. 2015. Role of arbuscular fungi in the nitrogen uptake of plants: current knowledge and research gaps. Agronomy 5: 587 612

Budi SW, Christina F. 2013 Coal waste powder amendment and arbuscular mycorrhizal fungi enhance the growth of jabon (Anthocephalus cadamba Miq) seedling in ultisol soil medium. J Trop Soils 18: 59-66

Budi SW, Setyaningsih L. 2013. Arbuscular mycorrhizal fungi and biochar improved early growth of neem (Melia azedarach Linn.) seedling under greenhouse conditions. Jurnal Manajenen Hutan Tropika 19: 103-110

Cardozo-Junior FM, Carneiro RFV, Goto BT, Bezerra AAC, Araújo ASF Nunes LAPL. 2012. Arbuscular mycorrhizal fungi in degraded lands in Northeast Brazil. Afr J Microbiol Res 6: 7198-7205.

Chen S, Zhao H, Zou C, Li Y, Chen Y, Wang Z, Jiang Y, Liu A, Zhao P, Wang M, Ahammed GJ. 2017. Combined Inoculation with multiple arbuscular mycorrhizal fungi improves growth, nutrient uptake and photosynthesis in cucumber seedlings Front Microbiol 8: 2516.

Delhaize E, Ryan PR. 1995. Alumunium toxicity and tolerance in plants Plant Physiol 107 (2): 315-321. DOI: 10.1104/pp.107.2.

Escobar OME, Hue NV. 2008. Temporal changes of selected chemical properties in three manure amended soils of Hawaii. Bioresour Technol 99: 8649-8654.

Furtini-Neto AE, Siquiera JO, Curi N, Moreira FMS. 2004. Fertilization in native species reforestation. In: Goncalves JLM, Benedetti V (eds.). Forest Nutrition and Fertilization. IPEF, Piracicaba, Brazil.

Gerdemann JW. 1975. Vesicular arbuscular mycorrhizae. In: Torrey JG, Clarkson DT (eds). The Development and Function of Roots. Academic Press, London.

Goussous JW, Mohammad MJ. 2009. Comparative effect of two arbuscular mycorrhizae and $\mathrm{N}$ and $\mathrm{P}$ fertilizers on growth and nutrient uptake of onions. Intl J Agric Biol 11: 433-467.

Guo Y, Ni Y, Huang J. 2010. Effects of rhizobium, arbuscular mycorrhiza and lime on nodulation, growth and nutrient uptake of Lucerne in acid purplish soil in China. Trop Grasslands 44: 109- 114.

Hetrick BAB, Wilson GWT, Todd TC. 1996. Mycorrhizal response in wheat cultivars: relationship to phosphorous. Can J Bot 74: 19-25.

Husna, Budi SW, Mansur I, Kusmana C. 2015. Growth response of kayu kuku (Pericopsis mooniana (Thw.) Thw.) seedling to indigenous arbuscular mycorrhizal fungi inoculation. Jurnal Pemuliaan Hutan Tanaman 9: 131-148

Husna, Mansur I, Budi SW, Tuheteru FD, Arif A, Tuheteru EJ, Albasari. 2019. Effects of arbuscular mycorrhizal fungi and organic material on growth and nutrient uptake by Pericopsis mooniana in coal mine. Asian J Plant Sci 18: 101-109.
Jayani FM, Budi SW, Pamoengkas P. 2018 Response of forest tree species inoculated with MycoSilvi and soil ameliorant addition grew in silica sand. Asian J Agric Biol 6: 556-565.

Jha A, Kumar A, Saxena RK, Kamalvanshi M, Chakravarty N. 2012. Effect of arbuscular mycorrhizal inoculation on seedling growth and biomass productivity of two bamboo species. Indian J Microbiol 55: 281-285.

Kochian LV, Hoekenga OA, Pineros MA. 2004. How do crop plants tolerate acid soils? Mechanisms of aluminum tolerance and phosphorous efficiency. Ann Rev Plant Biol 55: 459-493.

Kuzyakov Y, Xu X. 2013. Competition between roots and microorganisms for nitrogen: mechanisms and ecological relevance. New Phytol. 198: 656-669

Lambers H, Chapin FS III, Pons TL. 1998. Plant Physiological Ecology. Springer, New York.

Medina A, Azcon R. 2010. Effectiveness of the application of arbuscular mycorrhizal fungi and organic amendments to improve soil quality and plant performance under stress conditions. J Soil Sci Plant Nutr 10: 354-372.

Moreira FMS, de Carvalho TS, Siquera JO. 2010. Effect of fertilizer, lime, and inoculation with rhizobia and mycorrhizal fungi on the growth of four leguminous tree species in a low-fertility soil. Biol Fertil Soils 46: 771-779.

Mrabet SE, Ouahmane L, Mousadik AE, Msanda F, Abbas Y. 2014. The effectiveness of arbuscular mycorrhizal inoculation and bio-compost addition for enhancing reforestation with Argania spinosa in Morocco. Open J For 4: 14-23.

Jha A, Kumar A, Saxena RK, Kamalvanshi M, Chakravarty N. 2012. Effect of arbuscular mycorrhizal inoculation on seedling growth and biomass productivity of two bamboo species. Indian J Microbiol 55: 281-285.

Ohsowski BM, Dunfield K, Klironomos JN, Hart MM. 2017. Plant response to biochar, compost, and mycorrhizal fungal amendments in post-mine sandpits. Restor Ecol 26: 63-72

Pal A, Pandey S. 2017. Effect of arbuscular mycorrhizal fungi on chemical properties of experimental barren soil with pearl millet (Pennisetum glaucum L.) crop. Sci Technol 7: 82-86.

Plenchette C, Fortin JA, Furlan V. 1983. Growth response of several plant species to mycorrhizae in a soil of moderate P-fertility. I. Mycorrhizal dependency under field conditions. Plant Soil 70: 199-209.

Phyllips JM, Hayman DS. 1970. Improved procedures for clearing roots and staining parasitic and vascular arbuscular mycorrhizal fungi for rapid assessment of infection. Trans Br Mycol Soc 55: 158-161.

Renuka G, Rao MS, Kumar VP, Ramesh M, Reddy SR. 2012. Arbuscular Mycorrhizal Dependency of Acacia melanoxylon R. Br. Proc Nat Acad Sci India Sect B Biol Sci 83: 441-446.

Setyaningsih L, Wulandari AS, Hamin H. 2018. Growth of Typha grass (Thypa angustifolia) on gold-mining tailings with application of arbuscular mycorrhizal fungi. Biodiversitas. 19: 504-509.

Silva S. 2012. Alumunium toxicity targets in plants. J Botany. DOI: $10.1155 / 2012 / 219462$

Smith FA, Jakobsen I, Smith SE. 2000. Spatial differences in acquisition of soil phosphate between two arbuscular mycorrhizal fungi in symbiosis with Medicago tranculata. New Phytol 147: 357- 366.

Sultana J, Siddique MNA. 2015. Quantifying the role of arbuscular mycorrhizal colonization and acid phosphatase activity in grass biomass production. J Mol Med Res 1: 1-15.

Tawaraya K. 2003. Arbuscular mycorrhizal dependency of different plant species and cultivar. Soil Sci Plant Nutr 49: 665-668.

Wang P, Liu JH, Xia RX, Wu QS, Wang MY, Dong T. 2011. Arbuscular mycorrhizal development, glomalin-related soil protein (GRSP) content, and rhizospheric phosphatase activity in citrus orchards under different types of soil management. J Plant Nutr Soil Sci 174: 65-72.

Widyati E. 2006. Bioremediation of Former Coal Mining Land with Paper Industry Sludge to Spur Land Revegetation [Dissertations] IPB University, Bogor. [Indonesian]

Yamamoto Y. 2019. Aluminum toxicity in plant cells: Mechanisms of cell death and inhibition of cell elongation. Soil Sci Plant Nutr 65: 41-55. 